\title{
Deteksi dan Penggolongan Kendaraan dengan Kalman Filter dan Model Gaussian di Jalan Tol
}

\author{
Raditya Faisal Waliulu \\ Universitas Muhammadiyah Musamus Merauke
}

Naskah Diterima : 29 April 2017; Diterima Publikasi : 15 Maret 2018

DOI : 10.21456/vol8iss1pp1-8

\begin{abstract}
Monitoring systems are widely implemented in various sectors aimed at improving the security and productivity aspects. The research aims to detect moving objects in the form of video file tipefile (* avi) 640x480 resolution and image class according to pixel area. Moving objects are given in the Region of Interest path for easy detection. Detection on moving objects using methods of Kalman filter and gaussian mixture model. There are two types of distribution, the distribution of Background and Foreground. The form of the Foreground distribution is filtered using Bit Large Object segmentation to obtain the dimensions of the vehicle and morphological operations. The feature extraction results from the vehicle are used for vehicle classification based on pixel dimension. Segmentation results are used by Kalman Filter to calculate the tracking of moving object positions. If the Bit Large Object segmentation is not found moving object, then it is continued on the next frame. The final results of system detection are calculated using Positive True validation, True Negative, False Positive, and False Negative by looking for the sensitivity and specificity of each morning, day and night conditions
\end{abstract}

Keywords : Detection of Moving Objects; Recognition; Kalman Filter; Gaussian Mixture Model.

\begin{abstract}
Abstrak
Sistem pemantauan banyak dilakukan pada berbagai sektor bertujuan untuk peningkatan aspek keamanan dan produktivitas. Penelitian ini bertujuan untuk mendeteksi objek bergerak dalam bentuk file video tipefile (*.avi) yang beresolusi 640x480 dan golongan citra sesuai luas piksel. Objek bergerak diberikan pada lintasan Region of Interest untuk memudahkan pendeteksian. Deteksi pada obyek bergerak menggunakan metode Kalman filter dan model gaussian mixture. Terdapat dua jenis distribusi, yaitu distribusi Backgrounddan Foreground. Bentuk dari distribusi Foreground difilter menggunakan segmentasi Bit Large Object untuk mendapatkan dimensi dari kendaraan tersebut dan operasi morfologi. Hasil ekstrasi ciri dari kendaraan tersebut digunakan untuk penggolongan kendaraan berdasarkan dimensi piksel. Hasil Segementasi digunakan Kalman Filter untuk menghitung pelacakkan posisi objek bergerak. Jika segmentasi Bit Large Object tidak ditemukan objek bergerak, maka dilanjutkan pada frame berikutnya. Hasil akhir deteksi sistem dihitung menggunakan validasi True Positif, True Negatif, False Positif, dan False Negatif dengan mencari sensitifitas dan spesifisitas masing-masing kondisi pagi, siang dan malam.
\end{abstract}

Kata Kunci : Deteksi Objek Bergerak; Penggolongan; Kalman Filter; Gaussian Mixture Model.

\section{Pendahuluan}

Saat ini kebutuhan sistem pemantauan di berbagai sektor meningkat dengan pesat. Semakin banyak sistem pemantauan diterapkan untuk tujuan peningkatan aspek keamanan dan produktivitas. Penerapan pemantauan selalu berdasarkan pada kebutuhan pengawasan secara berkala dan merekam segala aktivitas yang berlangsung di lokasi tersebut dengan harapan ketika terjadi suatu hal kritis/penting, maka dapat segera diketahui dan ditangani.

Sistem pemantauan menerapkan deteksi objek bergerak, berbagai fasilitas publik seperti bandara, stasiun, jalan bebas hambatan (tol) hingga digunakan pada rumah tinggal. Dipertimbangkan karena bebagai macam aspek kebutuhan untuk digunakan pada deteksi wajah (Schneiderman dan Kanade, 2004), dan deteksi suhu panas (Anna, 2013) pada pemeriksaan koper bandara. Sedangkan penerapan sistem pemantauan untuk aspek produktivitas sebagai contoh diterapkan pada sektor manufaktur atau industri dimana manajemen dapat memonitor atau memantau aktifitas produksi para pekerja/buruh, mengkontrol instrumentasi proses dan instalasi permesinan.

Mendeteksi objek beregerak merupakan elemen penting dari berbagai vision komputer. Tujuan

*) Penulis korespondensi: klanwaliulu@gmail.com 
dasarnya adalah untuk menemukan atau identifikasi sebuah objek dari kelas yang telah ditetapkan dalam gambar statis atau frame video. Terkadang hal ini dapat dilakukan dengan mengekstraksi fitur gambar tertentu, seperti tepi, daerah warna, tekstur dan kontur. Setelah itu, beberapa heuristik diterapkan untuk menemukan konfigurasi dan/atau kombinasi dari fiturfitur karakteristik dari objek yang satu ingin untuk mendeteksi (Gon et al., 2012). Dibutuhkan sebuah teknik yang dinamis dan tidak terikat pada bentuk gerak objek pada background. Teknik ini hanya sementara digunakan selayaknya spatio-temporal. Seperti teknik spatio-temporal Gaussian mixture model (STGMM) dikemukakan oleh Soh et al. (2012). Setelah extraction, sebuah filter nonlinear mampu membantu deteksi posisi objek. Kemudian, Kalman filter digunakan untuk prediksi dan pembaruan lokasi objek (Julier dan Uhlmann, 2004).

Multiple object tracking sangat penting bagi peneliti terutama topik komputer vision. Mampu menangani objek tunggal serta pergantian pencahayaan background, gerak non rigid dan kesulitan muliti deteksi saat antara satu objek dan objek bergabung atau menyatu (MacCormick dan Blake, 2000). Membenahi angka objek. (Tao et al., 1999) Efisiensi algoritma mencari multiple objek (Hue et al., 2002). Ditujukan bayesian tracker untuk multiple tracking blob. Begitu banyak algrotima tracking yang diusulkan pada literatur, namun yang mencapai template dan local fiture adalah kalman filter (Raja et al., 1998).

Objek detektor bertujuan menemukan tiap wilayah pada gambar yang berisi contoh objek. Begitu banyak aplikasi objek deteksi yang menantang karena akurasi tinggi dibutuhkan ketika gambar dievaluasi pada kecepatan real-time (Sun, 2006) dan Miller et al. (2006). Seperti pendeteksi kendaraan, dimana salah satu kebutuhan untuk memperingatkan pengemudi tentang kemungkinan kecelakaan secepat mungkin dan tugas pengawasan dimana tiap video frame perlu diperiksa secara real-time untuk memeriksa pencurian (Viola dan Jones, 2001).

Kalman Filter metode bagian dari state space (ruang keadaan) yang dapat diterapkan dalam model prakiraan statistik. Sesuai dengan (Wei, 2006), metode ini menggunakan teknik rekursif dalam mengintegrasikan data pengamatan terbaru ke model untuk mengoreksi prediksi sebelumnya dan melakukan prediksi selanjutnya secara optimal berdasarkan informasi data di masa lalu maupun berdasarkan informasi data saat ini.

Berdasarkan (Welch dan Bishop, 2001), konsep Kalman Filter terdiri dari dua tahapan yakni peramalan dan pembaharuan. Pada tahap peramalan, dihasilkan nilai estimasi untuk keadaan (state) di waktu sekarang dan nilai kovarian error yang digunakan sebagai informasi estimasi awal untuk langkah selanjutnya. Tahap pembaharuan berfungsi sebagai korektor. Pada tahap ini dihasilkan pengukuran baru yang didapat dari nilai estimasi awal. Setelah kedua tahap terpenuhi, proses tersebut akan berulang kembali dengan nilai estimasi yang didapat dari tahap pengukuran digunakan sebagai informasi awal tahap peramalan yang kedua, begitu seterusnya hingga didapat nilai yang konvergen.

Penelitian ini bertujuan untuk mendeteksi objek bergerak dalam bentuk file video tipefile (*avi) yang beresolusi $640 \times 480$ dan golongan citra sesuai luas piksel. Objek bergerak diberikan pada lintasan Region of Interest untuk memudahkan pendeteksian. Perhitungan validasi menggunakan tingkat True Positif, True Negatif, False Positif, False Negatif untuk mendapatkan keakuratan kondisi penggolongan dan deteksi objek bergerak dijalan tol berdasarkan sensitifitas dan spesifisitas (Yadradj dan Ajay, 2013).

\section{Kerangka Teori}

\subsection{Gaussian Mixture Model (GMM)}

GMM adalah sebuah tipe density model yang terdiri dari komponen fungsi-fungsi Gaussian (Nicola et al., 2012) Komponen fungsi ini terdiri dari Threshold yang berbeda untuk menghasilkan multimodel density. Pada penelitian ini GMM digunakan untuk memodelkan warna-warna background dari tiap piksel. Hasil adaptasi terhadap perubahan yang terjadi dievaluasi melalui proses update parameter Weight, Standard Deviation, dan Means. Setiap piksel dikelompokkan berdasarkan distribusi yang dianggap paling efektif sebagai model latar belakang. Semakin besar nilai standar deviasi, semakin lebar distribusi kernel Gaussian maka, maka semakin kuat penghalusan yang terjadi pada citra.

Menggunakan algoritma GMM masih terlihat kurang sempurna, sehingga masih terlihat ada beberapa sedikit noise pada daerah sekitar obyek. Maka dari itu perlu ditambahkan suatu filter untuk menghilangkan noise disekitar obyek berupa filter Morfologi dengan menggunakan operasi Erosi, sehingga ukuran dimensi hasil segmentasi yang didapat mendekati ukuran yang sebenarnya.

\subsection{Operasi Morfologi}

Pengujian menggunakan Operasi Erosi bertujuan untuk memperhalus bentuk dari distribusi Foreground. Sehingga didapat fitur obyek mendekati dengan fitur obyek yang sebenarnya.

Hasil filter morfologi terhadap noise dari sebuah distribusi foreground dengan menggunakan filter erosi yang bertujuan untuk memperkecil bentuk dimensi kendaraan agar mendekati dengan ukuran sebenarnya, sekaligus mengurangi gerakan-gerakan kecil yang sekiranya tidak perlu untuk disegmentasi. Meskipun hasil tidak terlihat bersih sepenuhnya, namun kondisi ini sudah cukup baik untuk proses segmentasi. 


\subsection{Objek Filter}

Pada penelitian ini objek filter mengguanakan Metode Gaussian Mixture Model, membedakan bagian background dan foregorund, proses mengenali foreground untuk membandingkan objek frame video ke dalam background. Namun, metode ini tidak selalu beradaptasi dengan perubahan lingkungan seperti gangguan bayangan objek dan refleksi benda. Maka, dari itu ditambahkan fitur Morfologi sehingga segmentasi didapat mendekati ukuran sebenarnya.

\subsection{Segmentasi $B L O B$}

Threshold pada segementasi Blob ditentukan oleh batas nilai area minimal dan area maksimal, selain itu tidak akan dilakukan disegmentasi.

$$
B L O B=\min _{\text {area }} \leq T \geq \max _{\text {area }}
$$

Setiap piksel yang tergabung pada area Blob mempunyai nilai logika yang sama, suatu setiap piksel yang tergabung pada area Blob kan dianggap sebagai Foreground. Sedangkan piksel yang lain akan dianggap sebagai Background dengan memiliki nilai logika 1 .

\subsection{Kalman Filter}

Kalman filter terbagi menjadi dua state, prediksi dan koreksi. Kalman filter digunakan memprediksi keadaan dari linear sistem dimana keadaan tersebut di asumsikan oleh metode Gaussian. Kalman Filter terdiri dari 2 langkah, prediksi dan koreksi. langkah prediksi digunakan pada state model untuk memprediksi keadaan baru pada variable.

$$
\begin{gathered}
\bar{X}^{t}=D X^{t-1}+W \\
\bar{\Sigma}^{t}=D X^{t-1} D^{T}+Q^{T}
\end{gathered}
$$

Di mana suatu state dan prediksi kovarians pada saat t. D adalah state matriks transisi yang mendefinisikan hubungan antara variabel state. Waktu $\mathrm{t}$ dan $\mathrm{t}-1$. $\mathrm{Q}$ adalah kovarians dari kesalahan atau bobot W. Demikian pula, langkah koreksi menggunakan pengamatan saat ini untuk memperbarui keadaan objek:

$$
X^{t}=\bar{X}^{t}+K^{t}\left[Z^{t}-M \bar{X}^{t}\right]
$$

$\mathrm{M}$ adalah perhitungan matrix, $\mathrm{K}$ adalah bobot kalman. Catatan, state yang baru, didistribusikan oleh Gaussian. Kalman Filter, diasumsikan kalman filter adalah state yang di distribusikan oleh Gaussian.

\subsection{Validasi Penggolongan}

Hasil data citra yang dihitung menggunakan tingkat sensitifitas dan spesifisitas. Sensifitas, menghitung tingkat positif dimana rasio kesalahan ditemukan pada penggolongan. Sedangkan Spesifisitas, menghitung tingkat negatif dimana penggolongan kendaraan yang tidak salah sesuai penggolongan. Berikut persamaan yang di jabarkan.

Sensitifitas didapatkan dari True Postive. True Positive ditemukan dengan

$$
S_{n}=T p_{\text {rate }} \frac{T P}{T P+F N}
$$

Sensifitas didapatkan dari True Negative, kemungkinan pengelompokan.

$$
S_{n}=T N_{\text {rate }} \frac{T N}{T N+F P}
$$

\section{Metode}

\subsection{Prosedur Penelitian}

Prosedur penelitan dari Input video, deteksi kendaraan hingga penggolongan menggunakan metode kalman filter dan Gaussian seperti Gambar 1.

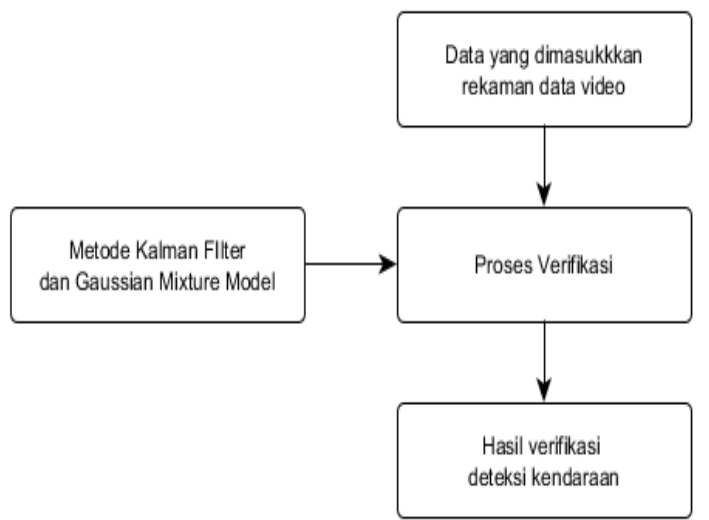

Gambar 1. Proses verifikasi data

Prosedur penelitian dapat dijelaskan secara rinci sebagai berikut :

1. Studi literatur

Pada tahapan ini, peneliti melakukan pengumpulan data-data untuk mendapatkan informasi dan teori melalui jurnal, literatur ilmiah, dan karya-karya ilmiah yang telah teruji kebenarannya mengenai Penerapan Kalman Filter dan Gaussian Mixture Model.

2. Analisa Kebutuhan Sistem

Setelah mendefinisikan masalah dan tujuan, sekarang pada analisa kebutuhan sistem. Tujuan penelitian melakukan observasi dengan objek penelitian kendaraan sebagai sampel untuk mendapatkan hasil permasalahan yang nyata dan data-data pendukung penelitian. Pengambilan data sampel akan dianalisis, dan diolah pada Kalman filter dan Gaussian Mixture Model. 
3. Tahapan Implementasi

Pada tahapan ini, dilaksanakannya penerapan sistem yang sudah jadi dan kemudian melakukan testing terhadap sistem dengan menggunakan data rekaman video yag sudah dikumpulkan sebelumnya. Setelah itu, dianalisis bahwa dari hasil simulasi yang dilakukan sudah sesuai dengan tujuan penelitian apa tidak. Jika sudah sesuai akan dilanjutkan ke tahapan kesimpulan.

4. Tahapan Kesimpulan

Tahapan ini mengambil kesimpulan yang didapat dari tahapan implementasi.

\subsection{Kerangka Sistem}

Kerangka sistem deteksi dan penggolongan digambarkan pada gambar 3.2. Sesuai dengan algroitma Kalman filter dan Gaussian Mixture Model.

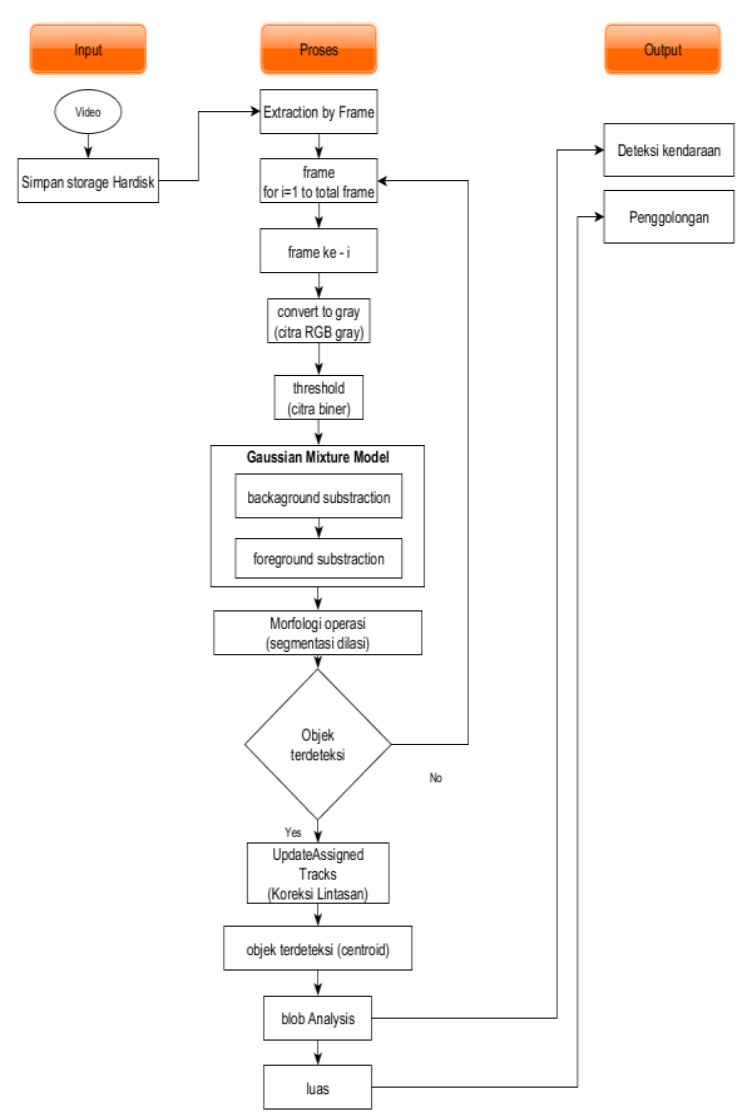

Gambar 2. Skema kerangka sistem informasi

Pada Gambar 2, menjelaskan tujuan untuk mentransformasikan kebutuhan-kebutuhan sistem yang dilakukan pada tahap analisis kebutuhan sistem kepada sistem model yang akan dibangun nantinya. Tahapan perancangan sistem mendesain aliran kerja sistem dan merancang pemrograman yang diperlukan dalam pembangunan sistem informasi. Alur kerja sistem dimulai dengan menentukan masukan, penyimpanan, pemrosesan, dan keluaran.

\section{Hasil dan Pembahasan}

\subsection{Proses Pengambilan Citra}

Guna mendapatkan hasil ekstraksi ciri dari suatu objek kendaraan dilakukan perhitungan terhadap besar jumlah piksel yang ada pada suatu bentuk citra. Besar piksel yang didapat akan digunakan sebagai data ekstraksi ciri. Dimana data tersebut mencerminkan informasi seperti panjang kendaraan dan lebar kendaran. Kalman filter, mendeteksi gerakan objek jika terdapat objek maka dilakukan segementasi melalui Gausian Mixture Model yang nantinya akan digunakan untuk thershold dan perhitungan.

Penerapan metode Kalman Filter dan Gaussian Mixture Model dalam program ini digunakan untuk mendeteksi dan penggolongan kendaraan dari frame dalam sebuah video yang di ekstrak dan diuji tiap framenya. Deteksi kendaraan dalam program ini, sebuah frame diambil diujikan melalui kalman filter yang memiliki dua tahap kerja pertama memprediksi objek yang memasuki ROI, setelah itu pada frame berikutnya tahap koreksi agar tidak dihitung 2 objek dengan frame yang berbeda maka tahap koreksi melakukan perhitungan dengan lintasan pada frame sebelumnya. Kemudian proses selanjutnya oleh Gaussian Mixture, melakukan segmentasi dan memperoleh dimensi kendaraan yang digunakan untuk penggolongan kendaraan.

Data uji yang digunakan pada penelitian ini adalah data rekam dijembatan jalan tol ketinggian 6 meter, kamera Pocket Sony tingkat zoom 4,1. Kulitas rekam 640x480 px filetype Avi. Berlokasi dijangli, Tembalang, kota Semarang, Jawa tengah dengan kordinat titik gps $(-7.024877,110.433334)$. Data rekam yang di ambil selama lima menit. Diuji dengan semenit pertama dan empat menit terakhir, dengan total lima menit.

Pengambilan ditunjukkan pada gambar 4.1, citra diambil dijalan Grand Candi Golf Semarang dengan kamera Sony 20 Megapixel dengan zoom 4.1 resolusi 640 x 480 px.

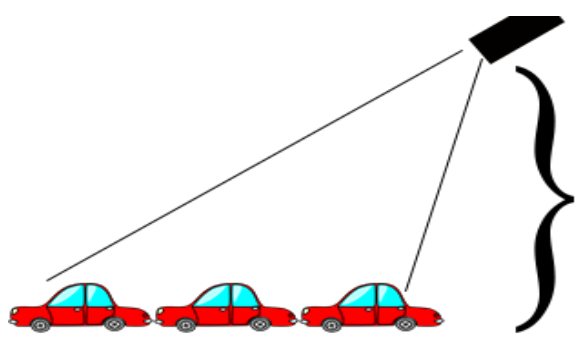

Gambar 3. Proses pengambilan citra

Pada Gambar 3, pemasangan kamera pengambilan citra dilakukan diatas jembatan penyebrangan dengan ketinggian 6 meter, ditunjukkan Gambar 4. 


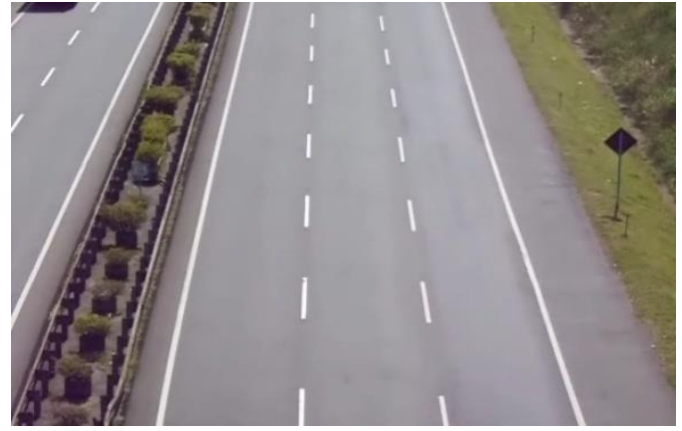

Gambar 4. Contoh citra jalan kosong

\subsection{Proses Pendeteksian}

Pada Gambar 5, pendeteksian dengan Kalman Filter dan Gausian Mixture Model. Dimulai dengan Input video (a), (b) lalu dilakukan greyscale (c), threshold (d) pada penghalusan threshold di ambil gerak benda dengan cara segmentasi dan akhirnya didapatkan evaluasi (f). Dilustrasi sebagai berikut :

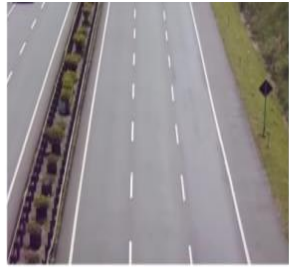

a). Citra jalan kosong

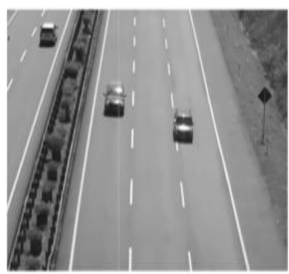

c). Grayscale

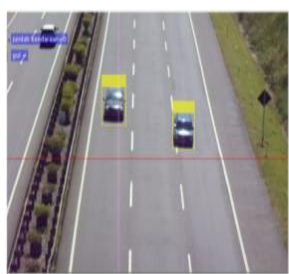

e). Evaluasi

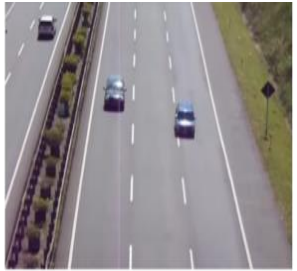

b). Citra Uji

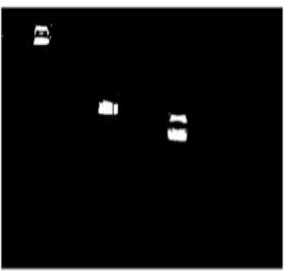

d). Threshold
Gambar 5. (a) Citra jalan input dari video, (b) Preprossing, (c) Citra grayscale, (d) Citra di segmentasi kemudian di operasikan morfologi, (e) Hasil akhir.

Tabel 1. Pengambilan waktu data citra

\begin{tabular}{ccc}
\hline Kondisi & detik & Frame \\
\hline Pagi & 60 & 1438 \\
(9:00) & 300 & 7192 \\
Siang & 60 & 1438 \\
$(15: 00)$ & 300 & 7188 \\
Malam & 60 & 1439 \\
$(20: 00)$ & 300 & 7188 \\
\hline
\end{tabular}

Terjadinya perbedaan frame karena bukan merupakan frame accurate artinya tidak semua frame terdeteksi pada file audio dan pada akhirnya hanya frame-frame yang terdeteksi saja yang akan di-encode. Frame-frame yang hilang ini bisa menyebabkan async audio, meskipun mestinya sangat halus dan tidak terasa (frame yang hilang biasanya tidak akan sampai $1 \%$ dari total frame).

\subsection{Pengujian Metode / Error}

Pada pengujian video didapatkan data yang dibagi menjadi tiga kondisi diantaranya : Pagi, Siang, Malam. Tiap kondisi tersebut dibagi kembali menjadi tiga waktu semenit, lima menit, dan sepuluh menit. Tiap pembagian hal tersebut setelah ditinjau lebih lanjut mendapatkan hasil yang signifikan terhadap pengujian video yang dilakukan. Berikut informasi yang didapatkan dari hasil perekaman video yang dilakukan dilapangan. Ditujukkan pada Tabel 2.

\begin{tabular}{cccccl}
\multicolumn{2}{l}{ Tabel 2. Informasi pengujian } & & & \\
\hline Kondisi & Detik & $\begin{array}{c}\text { Jumlah } \\
\text { frame }\end{array}$ & Deteksi & error & $\begin{array}{l}\text { Jumlah } \\
\text { kendaran }\end{array}$ \\
\hline pagi & 60 & 1438 & 21 & 4 & 29 \\
& 300 & 7192 & 98 & 22 & 120 \\
siang & 60 & 1438 & 17 & 4 & 22 \\
& 300 & 7188 & 86 & 28 & 114 \\
malam & 60 & 1439 & 4 & 0 & 4 \\
& 300 & 7188 & 23 & 20 & 43 \\
\end{tabular}

Tabel 3. Uji citra true positive, true negative, false negative dan false negative

\begin{tabular}{cccccl}
\hline Frame & TP & TN & FP & FN & Total \\
\hline 1438 & 24 & 0 & 0 & 5 & 29 \\
7192 & 73 & 12 & 0 & 35 & 120 \\
1438 & 17 & 0 & 0 & 5 & 22 \\
7188 & 77 & 8 & 0 & 31 & 114 \\
1439 & 4 & 0 & 0 & 0 & 4 \\
7188 & 23 & 5 & 5 & 10 & 43 \\
\hline
\end{tabular}

Tabel 3 didapatkan perhitungan validasi. Hasil data citra yang didapatkan dihitung menggunakan tingkat sensitifitas dan spesifisitas (Yadraj, 2013). Sensitifitas didapatkan dari True Postive. True Positive ditemukan pada rasio yang ditunjukkan pada Tabel 4.

Tabel 4. Tabel Sensitifitas dan Spesifisitas

\begin{tabular}{ccc}
\hline Kondisi & Sensitifitas & Spesifisitas \\
\hline Pagi & $68 \%$ & $100 \%$ \\
Siang & $72 \%$ & $100 \%$ \\
Malam & $52 \%$ & $50 \%$ \\
\hline
\end{tabular}

\subsection{Penggolongan Kondisi Pagi}

Pengolongan Pagi dimulai jam 9.00 WIB diambil data pada satu menit pertama atau jumlah 1438 frame, 
didapatkan berbagi dimensi kendaraani kendaraan kondisi pagi, Dari citra kendaraan yang didapatkan dibuat rentang penggolongan dari golongan satu hingga golongan lima, diberikan variabel $\mathrm{x}$ untuk range penggolongan seperti terlihat di Tabel 5.

Tabel 5. Rentang golongan kondisi pagi

\begin{tabular}{llll}
\hline & \multicolumn{3}{c}{ Dimensi } \\
\hline Golongan 1 & $0 \leq$ & Dimensi & $<30000$ \\
Golongan 2 & $30000 \leq$ & Dimensi & $<60000$ \\
Golongan 3 & $60000 \leq$ & Dimensi & $<70000$ \\
Golongan 4 & $70000 \leq$ & Dimensi & $<1000000$ \\
Golongan 5 & - & Dimensi & $\geq 1000000$ \\
\hline
\end{tabular}

\subsection{Performa Sistem Kondisi Cahaya Pagi}

Performa Sistem Kondisi Pagi. Berikut penyajian data citra yang diambil dalam bentuk histogram dan forgroundmask, ditunjukkan pada Gambar 6 .

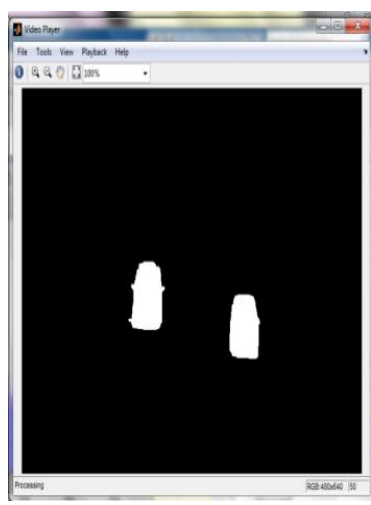

(a).Foregroundmask pagi

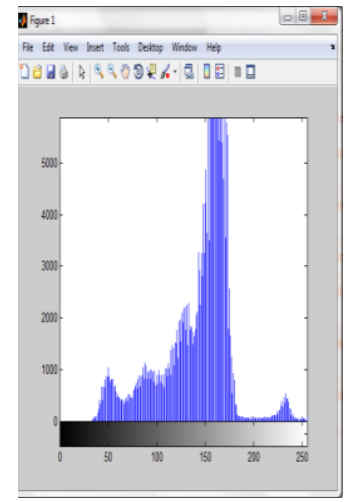

(b).Histogram pagi

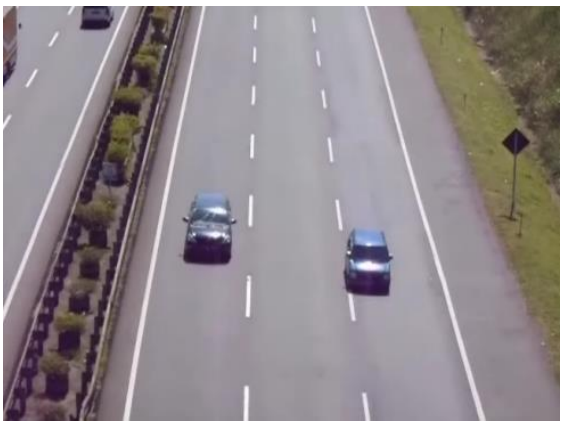

(c). Citra Pagi

Gambar 6. Performasi sistem pagi

Dengan kondisi pagi yang terlihat pada Gambar 4.26, sistem bekerja maksimal identifikasi deteksi kendaraan dan penggolongan. Data histogram di tunjukkan pada sumbu x diatas 100 , dengan katalain citra gambar cerah dan terang.

\subsection{Penggolongan Kondisi Siang}

Pengolongan Siang dimulai jam 15.00 wib diambil data pada satu menit pertama atau jumlah 1438 frame, didapatkan dimensi kendaraan kondisi siang. Dimensi kendaraan kondisi siang, dari citra kendaraan terdapat bayangan yang menempel pada mobil. Hal ini membuat bayangan sulit untuk dihilangkan sehingga pada siang hari dimensi lebih besar dari pagi. Rentang penggolongan dari golongan satu hingga golongan lima, diberikan variabel $\mathrm{x}$ untuk range penggolongan seperti terlihat di Tabel 6.

Tabel 6. Rentang Golongan Kondisi Siang

\begin{tabular}{llll}
\hline & & Dimensi \\
\hline Golongan 1 & $0 \leq$ & Dimensi & $<79000$ \\
Golongan 2 & $79000 \leq$ & Dimensi & $<89900$ \\
Golongan 3 & $89900 \leq$ & Dimensi & $<99990$ \\
Golongan 4 & $99990 \leq$ & Dimensi & $<1000000$ \\
Golongan 5 & & Dimensi & $\geq 1000000$ \\
\hline
\end{tabular}

\subsection{Performa Sistem Kondisi Cahaya Siang}

Performa Sistem Kondisi Siang. Disajikan seperti Gambar 7, data citra yang diambil dalam bentuk histogram dan forgroundmask.

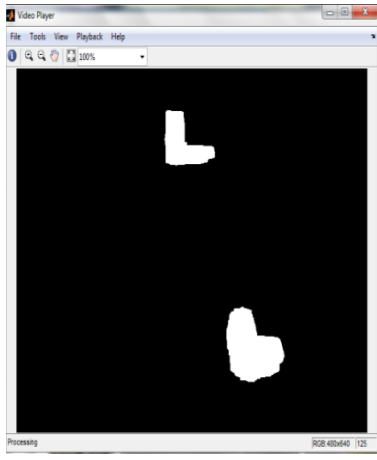

(a) Foreground Siang

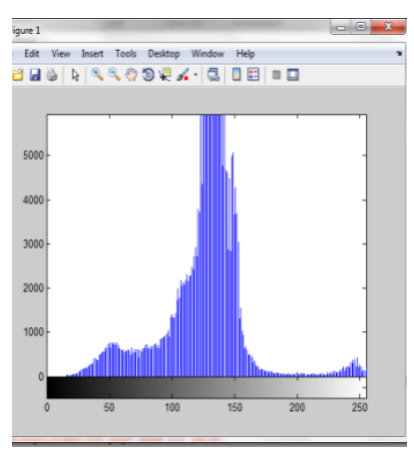

(b) Histrogram Siang

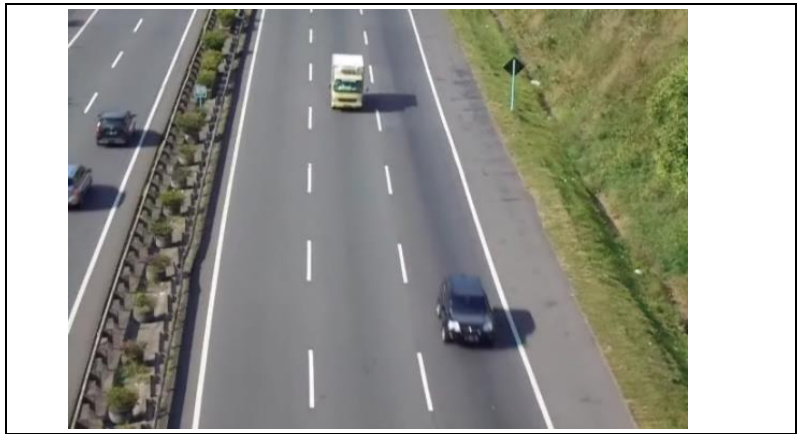

(c) Citra Siang

Gambar 7. Performasi sistem siang

\subsection{Penggolongan Kondisi Malam}

Penggolongan malam dimulai jam 20.00 wib diambil data pada satu menit pertama atau jumlah frame 1439 frame, didapatkan dimensi kendaraan kondisi malam. Kondisi malam deteksi kendaraan, dari citra kendaraan tidak terdapat bayangan yang menempel pada mobil. Namun, background (jalan) yang gelap didukung dengan kondisi cahaya yang minim membuat deteksi ini sulit untuk dilakukan. Sehingga background dan foreground terlihat sama yaitu gelap. 


\subsection{Performa Sistem Kondisi Cahaya Malam}

Performa sistem kondisi siang disajkan seperti gambar 8, data citra yang diambil dalam bentuk histogram dan forgroundmask. Seperti Gambar 8.

Dengan kondisi malam yang terlihat pada Gambar 4.28, sistem bekerja kurang maksimal identifikasi deteksi kendaraan dan penggolongan tidak tepat. Data histogram di tunjukkan pada sumbu x dibawah 100 , dengan kata lain citra gambar

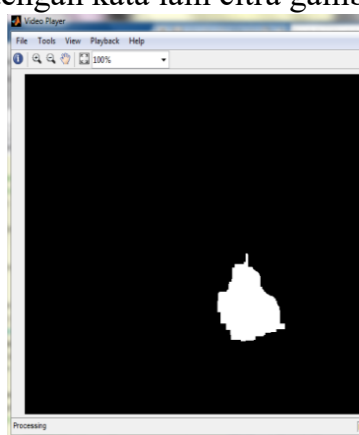

(a) Foreground Malam

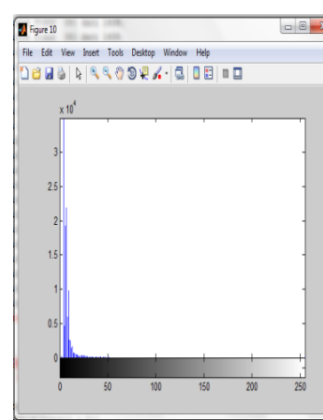

(b) Histogram Malam

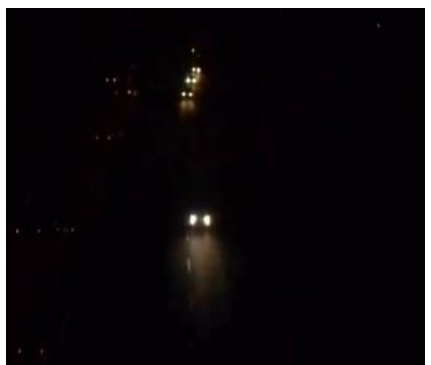

(c) Citra Malam

Gambar 8. Performasi Sistem malam

\section{Kesimpulan dan Saran}

Berdasarkan semua hasil pengujian yang dilakukan, pencahayaan sinar matahari pada siang hari dapat menimbulkan bayangan kendaraan pada badan jalan, sehingga dapat mempengaruhi dalam menentukan dimensi kendaraan baik panjang kendaraan maupun lebar kendaraan. Dikarenakan bayangan tersebut berubah bentuk dan bergerak secara terus menerus sehingga bayangan tersebut mengganggu foreground yang dihasilkan.

Pengambilan data video pada malam hari dengan pencahayaan lampu jalan, hanya kendaraan yang berwarna cerah yang dapat terdeteksi dengan baik. Sedangkan kendaraan dengan warna gelap tidak dapat terdeteksi dengan sempurna. Hal ini disebabkan karena pada saat proses filter dengan GMM warna foreground yang dihasilkan mirip dengan warna background.

Tingkat kerapatan jumlah kendaraan yang bergerak dapat mempengaruhi proses segmentasi dan dimensi kendaraan sehingga akan berpengaruh pula pada proses penggolongan, dikarenakan bayangan objek yang berdekatan akan membentuk satu objek foreground.

Perlu dilakukan pendeteksian kendaraan pada keadaan malam hari atau minim pencahayaan. Demikian juga, perlu dilakukan deteksi objek kendaraan yang bergerak cepat. Perlu mengoptimalkan objek kendaraan yang masuk dalam daerah ROI secara bersamaan, mencegah dianggap satu objek yang melewati. Algoritma yang dipakai dalam penilitain ini belum dapat mengenali jenis kendaraan secara sepesifik berdasarkan merek. Hal ini disebabkan karena ada beberapa jenis mobil memiliki variabel yang sama. Glare yang terjadi pada kaca mobil terhadap cahaya matahari menyebabkan dimensi lebar kendaraan menjadi lebih panjang pada citra threshold. Sistem ini masih perlu dikembangkan lebih lanjut, sehingga kelak mampu memberikan hasil yang lebih baik dalam mendeteksi jenis dan jumlah kendaraan yang lebih akurat untuk mencapai intelligent transport system.

\section{Daftar Pustaka}

Hue, C., Le Cadre,J.P dan Perez, P., 2000. Tracking multiple objects with particle filtering, Report Research, INRIA, Rennes.

Julier, S. J. Uhlmann, J. K., 2004. Unscented filtering and nonlinear estimation, Proceeding of the IEEE, 92 (3), 401-422.

MacCormick, J.P dan Blake, A., 2000. A probabilistic exclusion principle for tracking multiple objects. International Journal of Computer Vision 39 (1), $57-71$.

Miller, R., Sun, Z.,Bebis, G., 2006. On Road vehicle Detection. IEEE Transactions on Pattern Analysis and Machine Intelligence 28 (5), 694-711.

Raja, Y., McKenna, S.J, Gong, S., 1997. Segmentation and tracking using color mixture model. Proceeding Asian Conference on Computer Vision, Vol I, 607-614.

Schneiderman, H., Hoiem, D., Sukthankar, R., Huston, L., 2004. Object-based image retrieval using the statistical structure of images. Proceedings IEEE computer society conference on Computer vision and pattern recognition. Vol.2, pp 490-497.

Soh, Y.S, Hae, Y.S, Kim, I., 2012. Spatio-temporal gaussian mixture model for background modeling. IEEE International Symposium on Multimedia (ISM), 360-363.

Sun, Z., Bebis, G., Miller, R., 2006. On-road vehicle detection: a review", IEEE Transactions on Pattern Analysis and Machine Intelligence 28 (5), 694711.

Tao, H. Sawhney H.S, Kumar, R., 1999. A sampling algorithm for tracking multiple objects. Procceding of iternational Workshop on Vision Algorithms Corfu, Greece, September 21-22.

Viola, P., Jones, M.J., 2001. Rapid object detection using a boosted cascade of simple features. 
Proceedings of the Conference on Computer Vision and Pattern Recognition, Los Alamitos, CA, USA, 511-518.

Wei, Y., Jun, S., 2006. On Estimation and prediction for Multivariate Multiresolution Tree-Structured Spatial Linear Models, Statistica Sinica, 981-1020.
Welch, G dan Bishop, G., 2014. Kalman Filter. Computer Vision A Reference Guide, Springer, New York, 435-437.

Yadraj, M., Ajay, M., 2013. Blobs and Cracks detection on Plain Ceramic Tile Surface. International Journal of Advance Research in Computer Science and Software Engineering 3 (7), 647-652. 